\title{
Detection of Matrix Metalloproteinases by Zymography
}

\author{
Rajeev B. Tajhya*, Rutvik S. Patel ${ }^{*}$, and Christine Beeton ${ }^{*}, \#$ \\ *Department of Molecular Physiology and Biophysics, Baylor College of Medicine, Houston, Texas \\ 77030
}

\section{Summary}

Matrix metalloproteinases (MMPs) represent more than 20 zinc-containing endopeptidases that cleave internal peptide bonds, leading to protein degradation. They play a critical role in many physiological cell functions, including tissue remodeling, embryogenesis and angiogenesis. They are also involved in the pathogenesis of a vast array of diseases, including but not limited to systemic inflammation, various cancers, and cardiovascular, neurological, and autoimmune diseases. Here, we describe gel zymography to detect MMPs in cell and tissue samples and in cell culture supernatants.

\section{Keywords}

zymography; zymogram; protease; detection; semi-quantitative

\section{Introduction}

Matrix metalloproteinases (MMPs) are zinc-containing endopeptidases responsible for extracellular matrix degradation via cleavage of internal peptide bonds of specific proteins. More than 20 MMPs have been identified. MMPs can be either membrane-bound or secreted; they can be segregated into six groups based on their substrate specificity and structure: collagenases, gelatinases, stromelysins, matrilysins, membrane type, and others.

MMPs are crucial to development and tissue repair and remodeling but are also important players in many disease processes. They have been suggested as either diagnosis tools or therapeutic targets in a broad range of conditions such as multiple sclerosis [2,3], periodontal disease [4,5], cancer [7], rheumatoid arthritis and osteoarthritis [8,9], intestinal disease [10,11], or cardiovascular diseases [12]. The accurate and reproducible detection of different MMPs is therefore critical for both basic and translational research.

A number of techniques have been developed to detect and identify MMPs in various samples. Enzyme linked immunosorbent assays (ELISA) and Western blots require the use of antibodies targeted to the MMP of interest. Here, we describe the procedure for gel zymography, which was first described in 1980 by C. Heussen and E.B. Dowdle [13], and continues to be extensively used to detect MMPs in many cell types and tissues and in most bodily fluids $[4,8,3,5]$.

\footnotetext{
${ }^{\#}$ Correspondence should be addressed to C.B. (beeton@bcm.edu).
} 


\section{Materials}

Prepare all solutions using analytical grade reagents and ultrapure water. All solutions should be stored at room temperature in closed bottles unless otherwise specified and must be discarded after use following all waste disposal regulations in place.

\subsection{Buffers for sample preparation}

1. Phosphate-buffered saline (PBS), $\mathrm{pH} 7.2(1 \mathrm{X})$ : Add $800 \mathrm{~mL}$ water to a $1 \mathrm{~L}$ graduated cylinder. Weigh $8 \mathrm{~g} \mathrm{NaCl}, 0.2 \mathrm{~g} \mathrm{KCl}, 1.44 \mathrm{~g} \mathrm{Na}_{2} \mathrm{HPO}_{4}$ (dibasic anhydrous) (see Note ${ }^{1}$ ), and $0.24 \mathrm{~g} \mathrm{KH}_{2} \mathrm{PO}_{4}$ (monobasic anhydrous) and add to the graduated cylinder. Mix and adjust $\mathrm{pH}$ with $\mathrm{HCl}$. Add water to $1 \mathrm{~L}$ (see Note 2).

2. Protease inhibitor cocktail (100X): Add $16 \mathrm{~mL}$ water to a $20 \mathrm{~mL}$ graduated cylinder. Weigh $20 \mathrm{mg}$ aprotinin, $4 \mathrm{mg}$ leupeptin, $961 \mathrm{mg}$ benzamidine and add to the graduated cylinder. Add water to $20 \mathrm{~mL}$ and mix. Aliquot into microcentrifuge tubes and store at $-20^{\circ} \mathrm{C}$.

3. NP-40 lysis buffer, $\mathrm{pH} 7.5(1 \mathrm{X})\left(\right.$ see Note $^{3}$ ). Lysis buffer: Add $80 \mathrm{~mL}$ water to a $100 \mathrm{~mL}$ graduated cylinder. Weigh $394 \mathrm{mg}$ Tris- $\mathrm{HCl}$ and $584 \mathrm{mg} \mathrm{NaCl}$, and add to the graduated cylinder. Add $1 \mathrm{~mL}$ Nonidet P-40 (NP-40) to the graduated cylinder and mix. Add water to $100 \mathrm{~mL}$. Store at $4{ }^{\circ} \mathrm{C}$. Immediately before use, add $10 \mu \mathrm{L}$ of protease inhibitor cocktail (100X) (step 2.1.2 of the materials) to 1 $\mathrm{mL}$ of NP-40 lysis buffer.

4. Triton X-100 lysis buffer, $\mathrm{pH} 8.5$ (1X) (see Note $^{3}$ ): Add $80 \mathrm{~mL}$ water to a 100 $\mathrm{mL}$ graduated cylinder. Weigh $315 \mathrm{mg}$ Tris- $\mathrm{HCl}, 730 \mathrm{mg} \mathrm{NaCl}, 1 \mathrm{~mL}$ Triton X-100 ( see Note ${ }^{4}$ ) and add to the graduated cylinder. Add water to $100 \mathrm{~mL}$ and mix. Store at $4^{\circ} \mathrm{C}$. Immediately before use, add $10 \mu \mathrm{L}$ of protease inhibitor cocktail (100X) to $1 \mathrm{~mL}$ of Triton X-100 lysis buffer.

\subsection{Zymogram gel components}

1. Separating gel buffer: Add $80 \mathrm{~mL}$ water to a $100 \mathrm{~mL}$ glass cylinder. Weigh 4.63 $\mathrm{g}$ ammediol $\mathrm{HCl}$ and $0.02 \mathrm{~g}$ sodium azide and transfer to the cylinder. Mix and adjust $\mathrm{pH}$ to 8.96 with $\mathrm{HCl}$. Add water to $100 \mathrm{~mL}$. Store at $4^{\circ} \mathrm{C}$ for up to a month.

2. $10 \mathrm{X}$ casein substrate solution ( see Note ${ }^{5}$ ): Add $100 \mathrm{~mL} 0.1 \mathrm{~N} \mathrm{NaOH}$ to a glass beaker. Weigh $800 \mathrm{mg}$ casein and transfer to the beaker. Heat the solution to

\footnotetext{
${ }^{1}$ The $1.44 \mathrm{~g}$ of $\mathrm{Na}_{2} \mathrm{HPO}_{4}$ (dibasic anhydrous) can be replaced by $1.81 \mathrm{~g} \mathrm{Na} 2 \mathrm{HPO}_{4} \cdot 2 \mathrm{H}_{2} \mathrm{O}$ (dibasic dihydrate) or by $2.72 \mathrm{~g}$ $\mathrm{Na}_{2} \mathrm{HPO}_{4} \cdot 7 \mathrm{H}_{2} \mathrm{O}$ (dibasic septahydrate) in the preparation of PBS.

2 If PBS is to be kept more than a day, it can be sterilized to prevent bacterial growth by either autoclaving or sterile filtration $(0.22 \mu \mathrm{m}$ filter pores).

${ }^{3}$ Choice of the lysis buffer for protein extraction will depend on the specimen but also on the target MMP in the sample. For example, MMP-23 can only be efficiently extracted using the non-ionic detergent Triton X-100 [1].

${ }^{4}$ Triton X-100 is very viscous. When pipetting Triton X-100, only place the very tip of the pipet into the liquid to avoid coating the outside of the pipet with the detergent. Apply suction very slowly to allow the liquid to reach the correct volume in the pipet. If Triton $\mathrm{X}-100$ is visible on the outside of the pipet, remove it with a clean tissue. Empty the pipet very slowly into the receiving container already containing water and wait until the pipet has completely emptied (can take a few minutes).
} 
$37^{\circ} \mathrm{C}$ with occasional vortexing until full dissolution ( see Note ${ }^{6}$ ). Store at $-20^{\circ} \mathrm{C}$ for up to 6 months.

3. 10X gelatin substrate solution ( see Note ${ }^{5}$ ): Add $100 \mathrm{~mL}$ water to a glass beaker. Weigh $800 \mathrm{mg}$ porcine skin gelatin. Heat in the microwave until the solution just boils ( see Note ${ }^{7}$ ). Swirl thoroughly to ensure homogeneous distribution (see Note ${ }^{8}$ ). Store at $4^{\circ} \mathrm{C}$ for one week or at $-20^{\circ} \mathrm{C}$ for up to 6 months.

4. Sucrose solution: Add $50 \mathrm{~mL}$ water to a $100 \mathrm{~mL}$ glass cylinder. Weigh $50 \mathrm{~g}$ sucrose and $0.02 \mathrm{~g}$ sodium azide and transfer to the cylinder. Add $30 \mu \mathrm{L}$ toluene and make up to $100 \mathrm{~mL}$ with water. Store at $4^{\circ} \mathrm{C}$ for up to a month.

5. Separating gel ( see Note ${ }^{9}$ ): Mix the components in the appropriate proportions (Table 1) for the choice of gel ( see Note ${ }^{10}$ ).

6. Stacking gel buffer: Add $80 \mathrm{~mL}$ water to a $100 \mathrm{~mL}$ glass cylinder. Weigh $3.51 \mathrm{~g}$ ammediol $\cdot \mathrm{HCl}$ and $0.02 \mathrm{~g}$ sodium azide and transfer to the cylinder. Mix and adjust $\mathrm{pH}$ to 8.37 with $\mathrm{HCl}$. Add water to $100 \mathrm{~mL}$. Store at $4^{\circ} \mathrm{C}$ for up to a month.

7. Stacking gel ( see Note $^{9}$ ): Mix $142 \mu \mathrm{L}$ acrylamide/bisacrylamide solution (37.5:1), $285 \mu \mathrm{L}$ stacking buffer, $285 \mu \mathrm{L}$ sucrose solution, $428 \mu \mathrm{L}$ water, $14 \mu \mathrm{L}$ $10 \%$ (weight/volume) ammonium persulfate, and $3 \mu \mathrm{L}$ TEMED $\left(N, N, N^{\prime}, N^{\prime}\right.$ tetramethylethylenediamine) ( see Note ${ }^{11}$ ).

8. Tris- $\mathrm{HCl}, 0.5 \mathrm{M}, \mathrm{pH}$ 6.8: Add $400 \mathrm{~mL}$ water to a $1 \mathrm{~L}$ glass cylinder (see Note 12). Weigh $39.39 \mathrm{~g}$ Tris and transfer to the cylinder. Mix and adjust $\mathrm{pH}$ with $\mathrm{HCl}$. Add water to $500 \mathrm{~mL}$.

9. Sample buffer (2X): In a $10 \mathrm{~mL}$ glass cylinder, add $2.5 \mathrm{ml}$ of a $0.5 \mathrm{M}$ solution of Tris-HCl, pH 6.8, $2.0 \mathrm{ml}$ of glycerol, $10 \%$ (weight/volume) sodium dodecyl sulfate (SDS), and $0.1 \%$ (weight/volume) bromophenol blue. Add water to 10 $\mathrm{mL}$.

10. Running buffer (10X): To prepare $1 \mathrm{~L}$ of running buffer, add $100 \mathrm{~mL}$ water to a 1 $\mathrm{L}$ graduated cylinder. Weigh $29 \mathrm{~g}$ of Tris Base, $144 \mathrm{~g}$ of glycine, and $10 \mathrm{~g}$ of

\footnotetext{
${ }^{5}$ The choice of substrate in the gel will depend on the MMPs of interest. For example, MMP-2 and MMP-9 can be detected on gelatin gels, as can also be MMP-1, MMP-8, and MMP-13 although gelatin is not their preferred substrate. MMP-1 and MMP-13 are best detected on collagen gels while casein is the preferred substrate for MMP-11 and also allows for the detection of MMP-1, MMP-3, MMP-7, MMP-12, and MMP-13 [6]

${ }^{6}$ Full dissolution of casein is very important to ensure homogeneity of the separating gel during zymography. Lack of homogeneity will prevent data interpretation.

${ }^{7}$ Do not allow the solution to boil over as that would change its concentration.

${ }^{8}$ Full dissolution of the gelatin is very important to ensure homogeneity of the separating gel during zymography. Lack of homogeneity will prevent data interpretation.

${ }^{9}$ Pre-cast gels can be purchased from various vendors. These gels are provided in sealed pouches and have strict expiration dates; expired gels will not provide expected results as the substrate will have started degrading in a heterogeneous manner.

${ }^{10}$ The correct acrylamide percentage to use will depend on the molecular weight of the MMP of interest. Proteins with high molecular masses will resolve better on low percentage gels whereas proteins with low molecular masses will resolve better on high percentage gels. The $10 \%$ gels are the most commonly used for zymography as they resolve proteins between 20 and $100 \mathrm{kDa}$.

11 The volumes given here are sufficient for a single mini-gel $(9 \mathrm{~cm} \times 6 \mathrm{~cm} \times 0.75 \mathrm{~cm})$.

${ }^{12}$ Placing water at the bottom of the cylinder will help dissolve the Tris faster. In addition, warming the water to $37^{\circ} \mathrm{C}$ will hasten the dissolution of Tris. However, the solution should be brought to room temperature before adjusting $\mathrm{pH}$.
} 
SDS. Add all three to the graduated cylinder and add water to $1 \mathrm{~L}$. Mix with a magnetic stir-bar until fully dissolved.

\subsection{Buffers for protease detection}

1. Renaturing buffer (1X) (see Note ${ }^{13}$ ): Add $50 \mathrm{~mL}$ of water to a $100 \mathrm{~mL}$ graduated cylinder. Add $2.5 \mathrm{ml}$ of Triton X-100 to the cylinder (see Note ${ }^{4}$ ). Add water to $100 \mathrm{~mL}$ and mix thoroughly. Do not store for more than a day.

2. Developing buffer (10X): To prepare $1 \mathrm{~L}$ of developing buffer, add $100 \mathrm{~mL}$ water to a $1 \mathrm{~L}$ graduated cylinder. Weigh $12.1 \mathrm{~g}$ Tris Base, $63 \mathrm{~g}$ Tris- $\mathrm{HCl}, 117 \mathrm{~g} \mathrm{NaCl}$, $7.4 \mathrm{~g} \mathrm{CaCl}_{2}$ and add all four to the cylinder. Add $2 \mathrm{~mL}$ Brij 35 to the cylinder (see Note ${ }^{14}$ ). Add water to $1 \mathrm{~L}$ and mix thoroughly.

3. Coomassie Blue staining solution (1X) (see Note ${ }^{15}$ ): Add $800 \mathrm{~mL}$ water to a graduated cylinder. Add $50 \mathrm{~mL}$ methanol and $100 \mathrm{~mL}$ acetic acid (see Note ${ }^{16}$ ). Weigh $5 \mathrm{~g}$ Coomassie Blue R-250 and add to the graduated cylinder. Add water to $1 \mathrm{~L}$.

4. Coomassie Blue destaining solution (1X) ( see Note ${ }^{15}$ ): Add $800 \mathrm{~mL}$ water to a $1 \mathrm{~L}$ beaker. Add $100 \mathrm{~mL}$ methanol and $50 \mathrm{ml}$ acetic acid (see Note ${ }^{16}$ ). Add water to $1 \mathrm{~L}$.

\section{Methods}

Perform all procedures at room temperature unless otherwise specified and wear personal protective equipment.

\subsection{Sample Preparation}

\subsubsection{Preparation of Cell Culture Supernatants}

1. If the cells to be tested are adherent, plate in complete growth media and allow time to adhere ( see Note ${ }^{17}$ ).

2. Wash the cells 3 times with sterile PBS or serum-free culture media.

3. Incubate the cells at $37^{\circ} \mathrm{C}$ with serum-free culture media (see Note ${ }^{18}$ ) for the optimal duration dependent on the cells used ( see Note $^{19}$ ).

\footnotetext{
13 The renaturing buffer should be prepared fresh on the day it will be used.

${ }^{14}$ Brij 35 is very viscous. When pipetting Brij 35, only place the very tip of the pipet into the liquid to avoid coating the outside of the pipet with the detergent. Apply suction very slowly to allow the liquid to reach the correct volume in the pipet. If Brij 35 is visible on the outside of the pipet, remove it with a clean tissue. Empty the pipet very slowly into the receiving container already containing water and wait until the pipet has completely emptied (can take a few minutes).

${ }^{15}$ Coomassie Blue R-250 can be replaced by a ready-to-use commercial solution containing colloidal Coomassie blue G-250. An advantage of the colloidal Coomassie blue is that it only requires water (no methanol or acetic acid) for destaining.

16 Always add concentrated acid to a large volume of water; never add water to concentrated acid as this would result in a violent exothermic reaction.

${ }^{17}$ The number of cells to use for preparing cell culture supernatants for zymography will vary depending on the type of cells studied and must be tested prior to assays with a novel cell system. As a starting point, MMP-2 was detectable in the culture supernatants of human fibroblast-like synoviocytes isolated from patients with rheumatoid arthritis when cells were plated at a density of 50,000 cells per well with $0.3 \mathrm{ml}$ culture medium per well in a 24-well plate [14].

${ }^{18}$ Serum contains MMPs (Fig. 1); it is therefore crucial to remove all serum for the cell culture and then maintain the cells in serumfree media during MMP production. Indeed, any serum present in the culture may obscure effects from differential treatment of the cells (Fig. 2) $[15,14,16,10,4,8]$
} 
4. Collect the culture supernatants.

5. Proceed to measuring protein concentration (step 3.2 of the methods) or freeze at $-80^{\circ} \mathrm{C}$ until use (see Note ${ }^{20}$ ).

\subsubsection{Preparation of Cell Lysates}

1. If the cells to be tested are adherent, plate in complete growth media and allow time to adhere ( see Note ${ }^{21}$ ).

2. Wash the cells 3 times with sterile PBS or culture media.

3. Incubate the cells at $37^{\circ} \mathrm{C}$ with culture media for the optimal duration dependent on the cells used ( see Note ${ }^{19}$ ).

4. Place a bottle of PBS and a bottle of NP-40 lysis buffer on ice for a minimum of 20 min to prepare ice-cold buffers.

5. Wash the cells twice with ice-cold PBS.

6. Add cold NP-40 lysis buffer at a volume of $2 \mathrm{~mL}$ per $150 \mathrm{~mm}$ dish.

7. If the cells to be tested are adherent, scrape them using a cell lifter.

8. Collect the cell lysate and incubate on ice for $15 \mathrm{~min}$.

9. Centrifuge the cell lysate $16,000 \mathrm{~g}$ for $20 \mathrm{~min}$ at $4^{\circ} \mathrm{C}$ in a microcentrifuge.

10. Collect the supernatant.

11. Proceed to measuring protein concentration (step 3.2 of the methods) or freeze at $-80^{\circ} \mathrm{C}$ until use (see Note ${ }^{20}$ ).

\subsubsection{Preparation of Tissue Extracts - Technique 1: NP-40 lysis Buffer}

1. Place a bottle of NP-40 lysis buffer on ice for a minimum of 20 min to prepare ice-cold buffers.

2. Collect the tissue and process immediately.

3. Cut approximately $50 \mathrm{mg}$ of tissue into small pieces into a $1.5 \mathrm{~mL}$ microcentrifuge tube.

4. Add $0.5 \mathrm{~mL}$ of cold NP-40 lysis buffer (see Note ${ }^{22}$ ).

\footnotetext{
${ }^{19}$ The duration of incubation will differ with the cell types assessed and must be tested prior to assays with a novel cell system. As examples, when assessing MMP-2 levels in the culture supernatants of human fibroblast-like synoviocytes isolated from patients with rheumatoid arthritis or from rats with a model of rheumatoid arthritis, a $24 \mathrm{hr}$ incubation gave optimal results [14,16,3,4]. In contrast, rabbit corneal fibroblasts were cultured for $72 \mathrm{hr}$ before supernatant collection $[17,8]$ whereas a $1 \mathrm{hr}$ incubation was sufficient to detect pro-MMP-9 in the culture supernatants of human neutrophils [18,3].

20 It is crucial that MMPs are not denatured to remain functional. If the samples are to be frozen, they should be frozen immediately upon collection. In addition, every effort should be made to avoid repeated cycles of freezing and thawing of the samples.

${ }^{21}$ The number of cells to use for preparing cell culture supernatants for zymography will vary depending on the type of cells studied and must be tested prior to assays with a novel cell system. As a starting point, MMP-2 was detectable in the culture supernatants of human fibroblast-like synoviocytes isolated from patients with rheumatoid arthritis when cells were plated at a density of 50,000 cells per well with $0.3 \mathrm{ml}$ culture medium per well in a 24-well plate [14].

${ }^{22}$ The volume of lysis buffer to add will depend on the type of tissue to be homogenized as protein extractability varies with specimens.
} 
5. Homogenize the tissue with a pestle over ice.

6. Centrifuge the homogenate $16,000 \mathrm{~g}$ for $20 \mathrm{~min}$ at $4^{\circ} \mathrm{C}$ in a microcentrifuge.

7. Collect the supernatant.

8. Proceed to measuring protein concentration (step 3.2 of the methods) or freeze at $-80^{\circ} \mathrm{C}$ until use (see Note ${ }^{20}$ ).

\subsubsection{Preparation of Tissue Extracts - Technique 2: Pulverization}

1. Collect the tissue and immediately freeze with dry ice.

2. Pulverize the frozen tissue with a micro-dismembrator.

3. Weigh $50 \mathrm{mg}$ of pulverized tissue and resuspend in $0.15 \mathrm{~mL}$ Triton $\mathrm{X}-100$ lysis buffer under gentle rotation at $4^{\circ} \mathrm{C}$.

4. Centrifuge the homogenate $16,000 \mathrm{~g}$ for $20 \mathrm{~min}$ at $4^{\circ} \mathrm{C}$ in a microcentrifuge.

5. Collect the supernatant.

6. Proceed to measuring protein concentration (step 3.2 of the methods) or freeze at $-80^{\circ} \mathrm{C}$ until use (see Note ${ }^{20}$ ).

\subsection{Measuring Protein Concentration}

1. Remove the bovine serum albumin (BSA) standard reagent (see Note ${ }^{23}$ ) from $4{ }^{\circ} \mathrm{C}$ storage and let it warm to room temperature (see Note ${ }^{24}$ ). Invert a few times before use.

2. Prepare serial dilutions of $2 \mathrm{mg} / \mathrm{mL}$ BSA to create a calibration curve (linear) in the range of $200 \mu \mathrm{g} / \mathrm{mL}$ to $1000 \mu \mathrm{g} / \mathrm{mL}$.

3. Pipet each dilution of standard and the samples into separate clean cuvettes filled

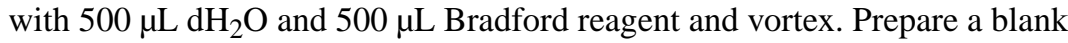

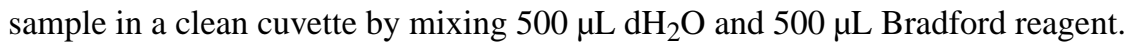

4. Incubate at room temperature (see Note ${ }^{24}$ ) for at least $5 \mathrm{~min}$. Do not incubate longer than $1 \mathrm{hr}$ at room temperature (see Note ${ }^{25}$ ).

5. Warm up the spectrophotometer for $10 \mathrm{~min}$. Zero the instrument with the blank sample. Measure the absorbance of the standards and the samples at $280 \mathrm{~nm}$.

6. Create a standard curve by plotting $280 \mathrm{~nm}$ readouts on the y-axis and concentration of the serial standard dilutions on the x-axis. Determine the slope of the standard curve.

7. Using the slope and $280 \mathrm{~nm}$ readouts, calculate the concentration of the samples (see Note ${ }^{26}$ ).

${ }^{23}$ While BSA is commonly used, any known protein standard can be used as a control.

${ }_{25}^{24}$ Cold solutions can condense atmospheric moisture on the outside of the cuvette and scatter light giving erroneous readings.

25 Absorbance of protein-dye conjugate increases over time and affects accuracy of protein concentration measurements.

26 If cell supernatants or tissue extracts contain low levels of gelatinases, a phase extraction with Triton X-114 is recommended [19]. 


\subsection{Gel Preparation}

1. Assemble the electrophoresis plates ( see Note $^{27}$ ).

2. Prepare the separating gel and immediately pour (see Note ${ }^{28}$ ) between the electrophoresis plates up to $2 \mathrm{~cm}$ from the top.

3. Overlay with water-saturated $n$-butanol and allow the gel to polymerize approximately $30 \mathrm{~min}$ at room temperature (see Note ${ }^{29}$ ).

4. Prepare the stacking gel (see Note ${ }^{28}$ ).

5. Decant the $n$-butanol from the gel and gently rinse with water (see Note ${ }^{30}$ ).

6. Pour the stacking gel on top of the separating gel.

7. Immediately insert the well comb (see Note ${ }^{31}$ ).

8. Allow the stacking gel to polymerize approximately $20 \mathrm{~min}$ at room temperature.

\subsection{Loading and Electrophoresis}

1. Remove the well comb from the gel and rinse gently with $1 \mathrm{X}$ running buffer.

2. Install the zymography gel in the electrophoresis setup.

3. Fill the inside chamber with $1 \mathrm{X}$ running buffer and the outside chamber with 500 $\mathrm{mL} 1 \mathrm{X}$ running buffer (see Note $^{32}$ ).

4. Place $10 \mu \mathrm{L}$ of $2 \mathrm{X}$ sample buffer on a Parafilm membrane and add $10 \mu \mathrm{L}$ of sample. Pipet a few times to mix and load the mixture into each well using gel loading pipet tips (see Note ${ }^{33}$ ).

5. Load a protein molecular weight standard in at least one well per gel.

6. Load appropriate recombinant MMP or a control known to contain the MMP of interest to identify the sample MMPs (optional) (see Note ${ }^{34}$ ).

7. Run the gel at $125 \mathrm{~V}$ for $90 \mathrm{~min}$ or until the loading dye reaches the bottom of the gel.

\subsection{Gel Renaturation}

1. Place $100 \mathrm{~mL}$ of $1 \mathrm{X}$ renaturing buffer in a container large enough to fit the whole gel flat.

\footnotetext{
${ }^{27}$ The electrophoresis plates must be completely clean and dry at this time or the gel could incompletely polymerize or polymerize in a heterogeneous manner.

28 Once the polymerization agent (TEMED) is added to the gel, immediately mix and pour as the gel will start polymerizing rapidly. If the gel polymerizes too fast, reduce the ambient temperature as this will delay polymerization.

${ }^{29}$ Ensure that the electrophoresis system is perfectly horizontal during gel pouring and polymerization.

30 It is crucial to remove all $n$-butanol to ensure full contact between the separating and stacking gels.

31 Place the comb carefully so as to not trap air bubbles.

32 Ensure that there is no leaking of the inside chamber buffer. If the inside chamber buffer leaks before sample loading, empty the gel box and unlock the gel. Wet the chamber gasket with running buffer and install the gel.

33 Volumes given here are for 12 -well gels. These volumes can and should be increased when loading a gel with fewer wells.

${ }^{34}$ Using recombinant MMPs as controls can be very useful for semi-quantification of the MMPs in the samples to be tested if various known concentrations are used. In addition, although MMPs are highly conserved between species in terms of molecular weight and protease activity, a positive control containing the MMP of interest in the species of choice would be beneficial.
} 
2. Open the gel plates (or cassette in the case of a commercial pre-cast gel).

3. Make a diagonal cut in a corner of the gel to mark its orientation.

4. Remove the gel from the plate or cassette ( see Note ${ }^{35}$ ).

5. Place the gel in the container with renaturing buffer.

6. Incubate for $30 \mathrm{~min}$ at room temperature with gentle agitation on a bench rocker.

\subsection{Gel Development}

1. Remove the renaturing buffer by gently pouring it into a waste container (see Note ${ }^{36}$ ).

2. Add $100 \mathrm{~mL}$ of $1 \mathrm{X}$ developing buffer to the container with the gel.

3. Incubate for $30 \mathrm{~min}$ at room temperature with gentle agitation on a bench rocker.

4. Remove the developing buffer by gently pouring it into a waste container

5. Add $100 \mathrm{~mL}$ of $1 \mathrm{X}$ developing buffer to the container with the gel. Close the lid tightly.

6. Incubate overnight $(16-18 \mathrm{hrs})$ at $37^{\circ} \mathrm{C}\left(\right.$ see Note $\left.{ }^{37}\right)$.

\subsection{Gel Staining and Destaining}

1. Remove the developing buffer by gently pouring it into a waste container.

2. Add $100 \mathrm{~mL}$ of water to the container with the gel.

3. Incubate for $5 \mathrm{~min}$ at room temperature with gentle agitation on a bench rocker.

4. Remove the water by gently pouring it into a waste container.

5. Repeat steps $2-4$ twice more.

6. Scan the gel to record the exact position of the protein standard bands as they will become difficult to see after gel staining and destaining.

\subsubsection{Staining with Coomassie Blue R-250}

1. Add $20 \mathrm{~mL}$ of Coomassie blue staining solution ( see Note ${ }^{15}$ ) to the container with the gel.

2. Incubate for $1 \mathrm{hr}$ at room temperature with gentle agitation on a bench rocker $\left(\right.$ see Note $\left.{ }^{38}\right)$.

3. Remove the staining buffer by gently pouring it into a waste container.

\footnotetext{
${ }^{35}$ Removing the gel from the plate or cassette is a tricky step as the gel is very fragile and easy to damage. It is safer to slide the gel off one side of the cassette rather than to try lifting it.

${ }^{36}$ When removing the buffer after incubating the gel, take precautions not to damage the gel. Wearing gloves, use two fingers to gently hold the gel at the bottom of the container while pouring the liquid out from one of the corners of the container.

${ }^{37}$ We recommend an overnight incubation in developing buffer. If, however, the bands are too strong, the developing time can be reduced to $4 \mathrm{hrs}$. If, in contrast, the bands are very faint, gels can be incubated in the developing buffer for up to $48 \mathrm{hrs}$.

${ }^{38}$ The gel should be stained in Coomassie Blue staining solution for 1 hour or until the gel is uniformly dark blue.
} 
4. Add $100 \mathrm{ml}$ of $1 \mathrm{X}$ destaining solution to the container with the gel.

5. Incubate at room temperature with gentle agitation on a bench rocker until areas of proteolytic activity are clearly visible (see Note ${ }^{39}$ ).

\subsubsection{Staining with colloidal Coomassie Blue (G-250)}

1. Add $20 \mathrm{~mL}$ of ready-to-use commercial buffer with colloidal Coomassie Blue to the container with the gel.

2. Incubate for $1 \mathrm{hr}$ at room temperature with gentle agitation on a bench rocker $\left(\right.$ see Note $\left.^{38}\right)$.

3. Remove the staining buffer by gently pouring it into a waste container.

4. Add $100 \mathrm{~mL}$ of water to the container with the gel.

5. Incubate for $1 \mathrm{hr}$ at room temperature with gentle agitation on a bench rocker (see Note ${ }^{40}$ ).

\subsection{Data Acquisition and Analysis}

1. Remove the gel from the water, place in a plastic sheet protector, and gently remove air bubbles.

2. Scan the gel with a digital scanner (see Note $\left.{ }^{41}\right)$.

3. The integrative intensity of the MMP bands can be quantified with ImageJ (freely available from the National Institutes of Health) or similar software.

\section{Acknowledgments}

This work was supported in part by funding from Baylor College of Medicine and National Institutes of Health grants AR059838 and NS073712 to CB.

\section{References}

1. Pei D, Kang T, Qi H. Cysteine array matrix metalloproteinase (CA-MMP)/MMP-23 is a type II transmembrane matrix metalloproteinase regulated by a single cleavage for both secretion and activation. J Biol Chem. 2000; 275(43):33988-33997. [PubMed: 10945999]

2. Baranger K, Rivera S, Liechti FD, Grandgirard D, Bigas J, Seco J, Tarrago T, Leib SL, Khrestchatisky M. Endogenous and synthetic MMP inhibitors in CNS physiopathology. Prog Brain Res. 2014; 214:313-351. [PubMed: 25410364]

3. Fainardi E, Castellazzi M, Bellini T, Manfrinato MC, Baldi E, Casetta I, Paolino E, Granieri E, Dallocchio F. Cerebrospinal fluid and serum levels and intrathecal production of active matrix

\footnotetext{
${ }^{39}$ If no zones of digestion are evident, use a positive control (e.g. recombinant MMP-2 or MMP-9 for gelatin gels and MMP-1 for casein gels). If these controls are visible, the test samples may be devoid of proteases specific to the chosen substrate or the MMP concentration may be lower than expected in which case increase the incubation time in developing buffer or concentrate the test samples. If these controls are not visible, check that (i) the samples were not boiled prior to gel loading as this would denature the proteins, (ii) the sample loading buffer does not contain anything that inhibits the proteases (e.g. EDTA), and (iii) the renaturing buffer contains sufficient amounts of Triton X-100.

${ }^{40}$ Destaining the gel stained with a ready-to-use commercial solution containing colloidal Coomassie Blue for an hour may not be optimal in all situations. More destaining can be obtained with a second incubation of $1 \mathrm{hr}$ in fresh water. The gel can be scanned multiple times during the destaining process to catch the best contrast in the bands.

${ }^{41}$ If the background contains blotches or streaks, this could indicate an uneven distribution of the substrate protein in the gel. Ensure that the gelatin of casein solution used to prepare the separating gel contains no undissolved materials
} 
metalloproteinase-9 (MMP-9) as markers of disease activity in patients with multiple sclerosis. Mult Scler. 2006; 12:294-301. [PubMed: 16764342]

4. Baeza M, Garrido M, Hernández-Ríos P, Dezerega A, García-Sesnich J, Strauss F, Aitken JP, Lesaffre E, Vanbelle S, Gamonal J, Brignardello-Petersen R, Tervahartiala T, Sorsa T, Hernández M. Diagnostic accuracy for apical and chronic periodontitis biomarkers in gingival crevicular fluid: an exploratory study. J Clin Periodontol. 2015 [Epub ahead of print].

5. Thomadaki K, Bosch J, Oppenheim F, Helmerhorst E. The diagnostic potential of salivary protease activities in periodontal health and disease. Oral Dis. 2013; 19:781-788. [PubMed: 23379269]

6. Snoek-van Beurden PA, Von den Hoff JW. Zymographic techniques for the analysis of matrix metalloproteinases and their inhibitors. Biotechniques. 2005; 37:73-83.

7. Cathcart J, Pulkoski-Gross A, Cao J. Targeting matrix metalloproteinases in cancer: bringing new life to old ideas. Genes Dis. 2015; 2:26-34. [PubMed: 26097889]

8. Cuéllar VG, Cuéllar JM, Kirsch T, Strauss EJ. Correlation of synovial fluid biomarkers with cartilage pathology and associated outcomes in knee arthroscopy. Arthroscopy. 2015 [Epub ahead of print].

9. Murphy G, Nagase H. Reappraising metalloproteinases in rheumatoid arthritis and osteoarthritis: destruction or repair? Nat Clin Pract Rheumatol. 2008; 4:128-135. [PubMed: 18253109]

10. Chang J, Wehner S, Schäfer N, Sioutis M, Bortscher S, Hirner A, Kalff JC, Bauer AJ, Overhaus M. Iatrogenic extracellular matrix disruption as a local trigger for postoperative ileus. J Surg Res. 2012; 178:632-639. [PubMed: 23079570]

11. Medina C, Radomski MW. Role of matrix metalloproteinases in intestinal inflammation. J Pharmacol Exp Ther. 2006; 318:933-938. [PubMed: 16644899]

12. Hopps E, Caimi G. Matrix metalloproteases as a pharmacological target in cardiovascular diseases. Eur Rev Med Pharmacol Sci. 2015; 19:2583-2589. [PubMed: 26221886]

13. Heussen C, Dowdle EB. Electrophoretic analysis of plasminogen activators in polyacrylamide gels containing sodium dodecyl sulfate and copolymerized substrates. Analytical Biochem. 1980; 102:196-202.

14. Hu X, Laragione T, Sun L, Koshy S, Jones KR, Ismailov II, Yotnda P, Horrigan FT, Gulko PS, Beeton C. KCa1.1 potassium channels regulate key pro-inflammatory and invasive properties of fibroblast-like synoviocytes in rheumatoid arthritis. J Biol Chem. 2012; 287:4014-4022. [PubMed: 22074915]

15. Hu X, Beeton C. Detection of functional matrix metalloproteinases by zymography. J Vis Exp. 2010; 45 pii 2445.

16. Tanner MR, Hu X, Huq R, Tajhya RB, Sun L, Khan FS, Laragione T, Horrigan FT, Gulko PS, Beeton C. KCa1.1 inhibition attenuates fibroblast-like synoviocyte invasiveness and ameliorates rat models of rheumatoid arthritis. Arthritis Rheumatol. 2015; 67:96-106. [PubMed: 25252152]

17. Pan H, Chen J, Xu J, Chen M, Ma R. Antifibrotic effect by activation of peroxisome proliferatoractivated receptor-gamma in corneal fibroblasts. Mol Vis. 2009; 15:2279-2286. [PubMed: 19936025]

18. Puente J, Jaque M, Carrasco C, Cruz C, Valenzuela M, Wolf M, Mosnaim A. Triptan drugs, natural killer cell cytotoxicity, and neutrophils pro-matrix metalloproteinase-9 secretion. Headache. 2008; 48:1482-1489. [PubMed: 18479418]

19. Toth M, Sohail A, Fridman R. Assessment of gelatinases (MMP-2 and MMP-9) by gelatin zymography. Methods Mol Biol. 2012; 878:121-135. [PubMed: 22674130] 

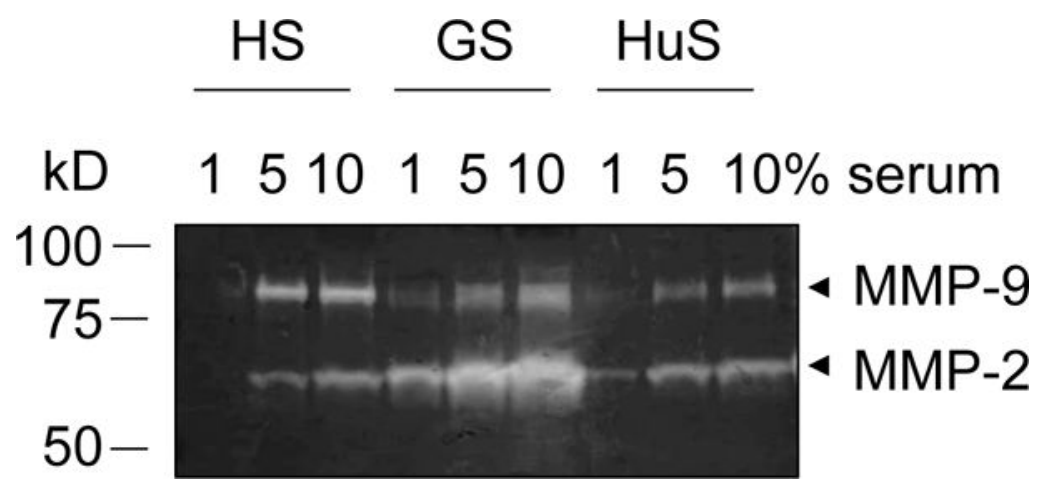

Figure 1.

Gelatin zymography gel loaded with different dilutions of horse serum (HS), goat serum (GS), and human serum (HuS) $(1,5,10 \%)$. Stronger bands of MMP-2 $(\sim 65 \mathrm{kD})$ and MMP-9 $(\sim 85 \mathrm{kD})$ are visible with increasing concentrations of the different sera. 


\section{RA-FLS \\ control paxilline}

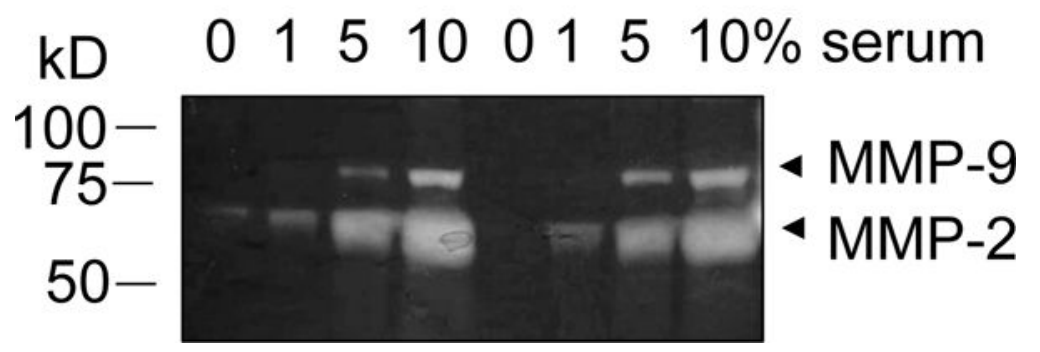

Figure 2.

Gelatin zymography gel comparing MMP-2 and MMP-9 production in the supernatant of untreated fibroblast-like synoviocytes isolated from a patient with rheumatoid arthritis (RAFLS; control) and paxilline-treated RA-FLS incubated in the presence of $0,1,5$, or $10 \%$ of fetal bovine serum. Paxilline-treated RA-FLS exhibit a decrease in MMP-2 production when incubated without serum. This effect is masked by incubation with 1, 5, 10\% serum. 


\section{Table 1}

Recipes for preparing zymogram separating gels with different percentages of acrylamide. The volumes are sufficient for a single mini-gel $(9 \mathrm{~cm} \times 6 \mathrm{~cm} \times 0.75 \mathrm{~cm})$.

\begin{tabular}{|l|c|c|c|c|}
\hline \multirow{2}{*}{ Solution } & \multicolumn{4}{|c|}{ Final acrylamide concentration in gel } \\
\cline { 2 - 5 } & $\mathbf{6 \%}$ & $\mathbf{7 . 5 \%}$ & $\mathbf{1 0 \%}$ & $\mathbf{1 2 \%}$ \\
\hline Acrylamide/bisacrylamide solution $37.5: 1$ & $0.8 \mathrm{~mL}$ & $1.0 \mathrm{~mL}$ & $1.32 \mathrm{~mL}$ & $1.61 \mathrm{~mL}$ \\
\hline Separating gel buffer & $1.0 \mathrm{~mL}$ & $1.0 \mathrm{~mL}$ & $1.0 \mathrm{~mL}$ & $1.0 \mathrm{~mL}$ \\
\hline $10 X$ casein or gelatin substrate solution & $0.4 \mathrm{~mL}$ & $0.4 \mathrm{~mL}$ & $0.4 \mathrm{~mL}$ & $0.4 \mathrm{~mL}$ \\
\hline Sucrose solution & $0.86 \mathrm{~mL}$ & $0.86 \mathrm{~mL}$ & $0.86 \mathrm{~mL}$ & $0.86 \mathrm{~mL}$ \\
\hline Water & $0.94 \mathrm{~mL}$ & $0.74 \mathrm{~mL}$ & $0.42 \mathrm{~mL}$ & $0.13 \mathrm{~mL}$ \\
\hline $10 \%(w / v)$ ammonium persulfate & $14 \mu \mathrm{L}$ & $14 \mu \mathrm{L}$ & $14 \mu \mathrm{L}$ & $14 \mu \mathrm{L}$ \\
\hline TEMED $*$ & $1.5 \mu \mathrm{L}$ & $1.5 \mu \mathrm{L}$ & $1.5 \mu \mathrm{L}$ & $1.5 \mu \mathrm{L}$ \\
\hline
\end{tabular}

"TEMED: $N, N, N^{\prime}, N^{\prime}$-tetramethylethylenediamine. 